\title{
Fact, Phenomenon, and Theory in the Darwinian Research Tradition
}

\section{Bruce H. Weber}

Department of Chemistry and Biochemistry

California State University Fullerton

Fullerton, CA, USA

bhweber@fullerton.edu

\&

Robert H. Woodworth Chair in Science and Natural Philosophy

Bennington College

Bennington, VT, USA

\begin{abstract}
From its inception Darwinian evolutionary biology has been seen as having a problematic relationship of fact and theory. While the forging of the modern evolutionary synthesis resolved most of these issues for biologists, critics continue to argue that natural selection and common descent are "only theories." Much of the confusion engendered by the "evolution wars" can be clarified by applying the concept of phenomena, inferred from fact, and explained by theories, thus locating where legitimate dissent may still exist. By setting such analysis in the context of research traditions, it is possible to gain further insight into the complex interplay of facts, phenomena, and theories. Two case studies are explored to assess the value of such approaches, one from within evolutionary biology, the Baldwin effect, and one from outside, intelligent design.
\end{abstract}

\section{Keywords}

Baldwin effect, Darwinian research tradition, Darwinism, evolution, fact, intelligent design, neo-Darwinism, phenomenon, research program, research tradition, theory 
Evolutionary theory was promulgated in a context of dissent and controversy that has continued through to the present. Disagreement among scientists about what counts as facts and how those facts are or are not explained by theories is a normal aspect of the practice of scientists. However, there is the added dimension with regard to evolutionary questions of the broader philosophical and theological implications in a wider public discourse. The recent Dover, Pennsylvania, trial was but one front in a broad "culture war" challenging the teaching about evolution in public schools with an "alternative" of "intelligent design" or ID (see for example Talbot 2005 and Humes 2007). Because these internal and external lines of dissent are often deliberately tangled in such debates, considerable confusion results.

In what follows I wish to offer several notions that I think help provide a perspective that can clarify what is at issue and how the arguments can be disentangled such that we can determine where the dissent and controversies are properly situated. This will also allow us to gain some insight into how science actually works and to distinguish productive from distracting dissent. The notions I wish to employ include foremost Bogen and Woodward's (1988) suggestion that the fact/theory distinction is inadequate and misleading and should instead be seen as interplay of data, facts, phenomena, and theories. To relate such interplay to Darwinism I will use the notion of a conceptual core of a research program as given a temporal dimension in the idea of a research tradition (Lakatos 1970, 1978; Laudan 1977; Depew and Weber 1995). In addition to exploring how such an approach helps clarify current debates about Darwinism, I will examine how it can give insight into a particular evolutionary question, that of the so-called Baldwin effect, where there has been a complex, shifting pattern of dissent and argument about facts, phenomena, and theory (Weber and Depew 2003).

\section{Data, Facts, Phenomena, and Theories}

The issue of facts and theories has become part of the general discourse about whether and/or how evolution should be taught in public schools in the US. The current mantrum of creationists and intelligent-design theorists is that "evolution is only a theory" - not a fact but just a guess. Indeed, a school board in Georgia ordered just such a label to be placed in secondary school biology textbooks, stating "Evolution is a theory, not a fact, regarding the origin of living things" (and as is normal in the US the issue was litigated and a Federal judge ordered the labels removed, see http://www.aclu.org/ReligiousLiberty.cfm for the case history and judgment). In contrast, Darwinians such as Michael Ruse claim that "evolution is fact, fact, FACT!" (Ruse 1982: 58; italics in original). Stephen Jay Gould, in reaction to Justice Scalia's dissent in Edwards v. Aguillard, in which Scalia suggested that there was not conclusive evidence in support of evolution, wrote:

Well, evolution is a theory. It is also a fact. And facts and theories are different things, not rungs in a hierarchy of increasing certainty. Facts are the world's data. Theories are the structures of ideas that explain and interpret facts. Facts do not go away while scientists debate rival theories for explaining them. Einstein's theory of gravitation replaced Newton's but apples did not suspend themselves in midair pending the outcome. And human beings evolved from apelike ancestors whether they did so by Darwin's proposed mechanism or by some other, yet to be discovered. (Gould 1983: 254)

Reacting in turn to this passage, one of the chief proponents of ID, Philip Johnson, wrote:

The analogy is spurious. We observe directly that apples fall when dropped, but we do not observe a common ancestor for modern apes and humans. What we observe is that apes and humans are physically and biochemically more like each other than they are like rabbits, snakes or trees. The ape-like common ancestor is a hypothesis in a theory, which purports to explain how these greater or lesser similarities came about.

... The "fact" that Gould describes is therefore nothing but Darwin's theory rightly understood: evolution is descent with modification propelled by random genetic changes, with natural selection providing whatever guidance is needed to produce complex adaptive structures like wings and eyes. (Johnson 1993: 67)

One might be tempted to say that here, "Confusion hath made its masterpiece." Is evolution a fact, a theory, both, or a hypothesis within a theory? This is where Bogen and Woodward provide valuable insight. In their account, data are produced by observation and/or experiment, which -if not falsified in some manner or shown to be artifacts of the experimental system, and in particular if supported by different means of measurement - can come to be accepted as facts about nature by a group of scientists. Facts are not found in the same way as pebbles on a beach, they are made by empirical observations that a community of scientists come to accept. But even when data are accepted as facts, it is not these facts per se that are explained by theories but rather the inferences from such facts, or the phenomena, which have the stability that allows significantly different lines of evidence (what William Whewell (1837) termed "consilience of inductions") to demonstrate their existence. For example, although specific data about the relative positions of the planets were the result of observations, Kepler's three laws of planetary motion are the phenomena that were inferred by Kepler from the data. Such inferred factual claims about nature, phenomena, although not directly observed, can also be regarded as scientific facts. Newton later provided an explanation of why Kepler's phenomenological laws have the form they did through his theory of universal gravitation. If Newton's theory were replaced by Einstein's, the phenomena 
would still exist and would need to be explained by the new theory. Thus Gould's analogy should have been that descent with modification-or more generally common descent-is a phenomenon that Darwin's theory of natural selection explains; and even if Darwin's theory is modified, falsified, or replaced, common descent is not automatically being doubted. Gould is guilty of conflating facts and phenomena. But of course, in the Bogen-Woodward view, Johnson is confusing theory with phenomena. We will return to the phenomenon of common descent and the theories, Darwin's and others, that attempt to provide causal explanations.

Perhaps another example will help demonstrate the application of the Bogen-Woodward thesis. During the middle half of the 20th century, one of the major problems for biochemists was to understand how aerobic cells converted the energy in foodstuffs (or in the case of plants, light energy) into ATP, the "energy currency" used to drive most other chemical, osmotic, and mechanical work in living beings. It was shown that the phenomenon, called oxidative phosphorylation, involved proteins embedded in membranes and coupled the consumption of oxygen (or light photons) and the phosphorylation of ADP to ATP. Compounds, known as "uncouplers," could, as their name suggests, uncouple the membrane reactions of electrons from foodstuffs to oxygen from the production of ATP. There was a theory, the "chemical theory," that postulated a series of coupled, membrane-bound, enzyme-catalyzed chemical reactions and intermediates analogous to those that had recently been identified in metabolic reactions occurring in the cytosol catalyzed by soluble enzymes. However, the chemical structure of the various compounds that acted as uncouplers showed an unprecedented variety not seen in other metabolism. In 1961 Peter Mitchell in Edinburgh and Bob Williams in Oxford proposed radically different explanatory theories from the chemical one, in which protons provided the causal, energetic coupling (see Prebble and Weber 2003 for an account of this history). In particular, Mitchell's theory provided a simple and elegant explanation of uncouplers; they only had to be lipidsoluble and have an ionizable group in order to dissipate the linking proton gradient. Mitchell's theory (originally a hypothesis but a theory by the time he received the Nobel Prize in 1978) not only provided an explanation of the phenomenon but also explained additional phenomena with regard to membrane potential, coupled transport of various metabolites with proton translocation, while unifying the study of oxidative phosphorylation and photosynthesis. There was plenty of dissent and controversy during the "ox-phos" wars of the 1960s and 1970s that continued even past Mitchell's death in 1992. When Michael Mulkay interviewed a number of leading scientists in the field of bioenergetics, he was confused by the controversies and frequent statements by participants in the research community that accepted Mitchell's proposed role of protonic coupling while often rejecting his specific mechanisms (Gilbert and Mulkay 1984; Mulkay 1985). Initially, there were fights over the data and whether there was experimental evidence to support the notion of a phenomenon of an energy-conserving proton gradient. When the proton gradient (including a pH and a membrane potential difference) was generally accepted, the argument shifted to the exact mechanisms by which such gradients were generated and utilized. While Mitchell's theory stood up well in one case (the "Q-cycle"), it required major modification as suggested by Paul Boyer (Nobel Prize 1997) to explain satisfactorily how ATP is actually synthesized. One lesson from the ox-phos case is: Not only does Bogen-Woodward bring conceptual clarification, but the relationship of data, facts, phenomena, and theory is itself changing over time. Thus a research program can change via changing auxiliary assumptions by which the core is connected to the world. By which route we come to the need to consider research traditions and how they enter the Bogen-Woodward mix.

\section{Research Traditions}

David Depew and I have utilized the notion of a research tradition to understand the broader sweep of changes in Darwinism over the past century and a half (Depew and Weber 1995; Weber and Depew 1996). We were drawn to this because the reaction of some to developments such as the neutral theory of molecular evolution, attempts to integrate developmental systems into evolutionary theory, observations of the role of epigenetic factors in heritable variation and retroviruses and retrotransposons in the evolution of biological functions such as the immune system was to characterize such developments as evidence for non-Darwinian evolution, even for Lamarckian evolution (Jablonka and Lamb 1995; Jablonka 2001; Steele et al. 1998; for a discussion see Weber and Depew 2001 and Aronova 2007). We found that by considering changes in the systems dynamics that were part of the background and auxiliary assumptions as the original Darwinian research program changed into that of the modern evolutionary synthesis or neo-Darwinism, we could understand how the continuity of the core concept of natural selection was modified from a Newtonian systems dynamic into a probabilistic one that both sharpened and deepened understanding of natural selection. Such a description fit comfortably with Laudan's extension of Lakatos's research program into a longer diachronic process that he termed a research tradition. For Laudan, the identification of a stable core as distinguished from modifiable auxiliary assumptions can be delineated only retrospectively. As James Moore has pointed out, Darwinism initially was defined by Thomas Huxley as common descent by natural means, where the means were understood to be primarily but not limited to natural selection; indeed it was a plausible strategy at that time, given the complex intellectual and political environment, not to tie Darwinism solely to a then largely hypothetical natural 
selection (Moore 1991). Darwinism was defined by some of Darwin's critics, then as now, for their own purposes as merely a synonym for philosophical materialism or metaphysical naturalism (see for example Bree 1872; Johnson 1993, 2000). Viewed from the vantage point of the present, when natural selection is a well-established phenomenon and natural mechanism, it is possible to see a commitment to natural selection as the constant core of Darwinism (Depew and Weber 1995). Although the program of the modern evolutionary synthesis was different in important aspects from that of "Darwin's Darwinism," it clearly can be recognized as being part of the same research tradition and distinguished from other research traditions, such as Lamarckism, Geoffroyism, Spencerism, orthogenesis, and so forth. We went on the analyze the ways in which incipient utilization of complex systems dynamics might bring about a similar new synthesis, extending the existing one to incorporate new knowledge from molecular and developmental biology. Seen through this lens, the relationship of facts, phenomena, and theory would also be expected to change in subtle ways, but still be recognizably part of the Darwinian research tradition. When I use the term "Darwinism" it is in reference to this notion of the Darwinian research tradition.

\section{Fact, Phenomenon, and Theory in the Darwinian Research Tradition}

In the Origin of Species Darwin presented one long argument that had two principal components, one a factual claim about an inferred phenomenon - common descent - and an explanatory theory of natural selection, and not a great deal of factual evidence for either. Barry Gale (1982) has gone so far as to characterized Darwin's argument as "evolution without evidence" asserting that Darwin had no more evidence than the creationists of his time but knew he had a better "theory by which to work." This echoes the point made by Darwin's first critics, especially Louis Agassiz, who argued that he presented no new facts, and that what facts there were, were better explained by invoking special creation (see Bree 1872 for a summary of these types of arguments). Darwin did not use the term "phenomenon" to characterize common descent; sometimes he himself referred to it as a "theory," thereby adding confusion for both his critics and friends. Most often he presented common descent as a hypothesis that made sense of a number of lines of evidence, including taxonomy, comparative anatomy and embryology, the fossil record, and-in Darwin's mind most compellingly — biogeography, all of which had significant (if incomplete by the standard current knowledge) factual bases. In this he was following Whewell's criterion of a "consilience of inductions" with its implication of a, at least putative, phenomenon.

The current argument that evolution is "only a theory" was made early on. Charles Bree (1872) argued that the claim of common descent was only a conjecture not based upon facts and indeed was itself just a theory that Darwin then explained by his theory of natural selection. Bree also attacked the writings of Tyndall, Hooker, Huxley, and Spencer, all under the rubric of Darwinism, which for Bree and others (down to today) meant philosophical materialism. But of course Darwin based his inference of common descent upon the wide range of types of evidence to which he alluded in the Origin and information about variation in plants and animals, which was part of his projected volume of which the Origin was but an "abstract," which was ultimately published by Darwin separately in The Variation of Animals and Plants under Domestication (Darwin 1868). Although barnacles got only a passing mention in making the "long argument," Darwin's technical work on barnacles, published only in the professional literature, formed an important part of his confidence in inferring common descent (Darwin 1851, 1854, 1858).

Natural selection was also criticized as having no foundation in fact. While the possible action of natural selection was illustrated mainly by thought experiments, Darwin did adduce some lines of evidence in terms of the problems of distinguishing varieties and species and the lack of absolute perfection of traits that made sense in light of natural selection but not in terms of special creation. In the first four chapters of the Origin, Darwin argues first for artificial selection acting upon heritable variation in domestic species as in effect a Herschelian vera causa (Depew and Weber 1995). Just as the action of the force of gravity on the moon could not be directly observed but rather that of centrifugal and centripetal forces in terrestrial experiments, so natural selection acting over generational and geological time could not be expected to be directly observed but artificial selection could. Indeed this analogy could be worked out in a metaphorical Newtonian systems dynamics that Darwin borrowed from the economists (Depew and Weber 1995). The rest of the argument was to establish variation in nature, and then deduce (via the economic metaphor) the struggle for existence, and that over time the resulting natural selection would produce adaptation or extinction. Thus Darwin was able to explain the apparent design of adapted functional complexity that was the basis of William Paley's (1802) argument from design. Darwin would subsequently show how natural selection could explain the coadaptation of traits in orchids and insects, thus further refuting the ID of his day, which postulated such co-adaptations as the result of special creation by the designer (Darwin 1862; see also Ghiselin 1969). Then, crucially, Darwin went on to argue that such a selective principle, in analogy to what happens in economic systems, would be expected to produce descent with modification, an increasing diversity and biomass in the economy of nature, and ultimately explain common descent. Depew and I argued that "Darwin's delay" in publishing in 1859 rather than 1844 was due to his need to work out how 
natural selection could give a causal account of diversification and descent with modification (the sole illustration in On the Origin of Species serves to illustrate this point about diversification being a consequence of natural selection) and thus of common descent (Depew and Weber 1995).

Rather than characterizing common descent as a theory, it reduces confusion if it is regarded as an inference from (initially limited) observations to a phenomenon with natural selection as Darwin's main theory to explain the phenomenon of common descent (Depew and Weber 1995; Hofmann and Weber 2003). This separates the possibility of the phenomenon of common descent (often conflated with evolution) from the particular mechanism used to explain it. In the 1860s there could be a legitimate scientific debate as to whether common descent was a real phenomenon of nature or not. In 1863 Fritz Müller published in Für Darwin (published in English in 1869) a summary of factual evidence that supported the claim of common descent within a particular group, the crustacea; the evidence marshaled did not address the issue of natural selection (Müller 1869). Interestingly, he couched his project in falsificationist terms:

In the first place, Darwin's suppositions when thus applied might lead to irreconcilable and contradictory conclusions, from which the erroneousness of the suppositions might be inferred. If Darwin's opinions are false, it was to be expected that contradictions would accompany their detailed application at every step, and that these by their cumulative force, would entirely destroy the suppositions from which they proceeded, even though the deductions derived from such particular might possess little of the unconditional nature of mathematical proof. (Müller 1869: 1-2)

Alternatively, such an attempt could not only provide support for Darwin but allow the construction of a "genealogical tree" for the group: on the other hand, the results could be inconclusive. He concludes that common descent was not falsified and that a general picture of the class of crustacea can be discerned even if there was not yet sufficient information to allow construction of a reliable tree. Although his work in no way tested Darwin's theory of natural selection, Müller (1869: 114-115) concluded that it provided a plausible explanation of the patterns observed. Others, while accepting common descent as a phenomenon, rejected natural selection as causally inadequate to do the job (Mivart 1871). This is a refrain repeated by Michael Behe (1996) with his claim of "irreducible complexity" that cannot be produced by natural selection.

\section{After Darwin}

In the immediate decades after Darwin's death evidence accumulated supporting common descent and some initial attempts were made to find evidence for the action of natural selection. Today the evidence from a number of lines of research is overwhelming to most biologists that common descent is a phenomenon so well established that it would be considered a waste of time, if not "perverse to withhold provisional consent" (Gould 1983: 254), or to base a research program assuming its falseness. Evidence is also overwhelming that natural selection occurs as a natural phenomenon and even some creationists and self-styled ID "theorists" accept it as something real, although they reject its possible causal efficacy in producing adaptation, common descent, or biological novelties (Johnson 1993; Behe 1996; Sarfati 2002).

Between Darwin's death in 1882 and the emergence of the Modern Evolutionary Synthesis, or neo-Darwinism, in the 1930s and 1940s, Darwinism was considered by many to be in crisis because of the challenge from mutationism and Mendelism more generally as well as Weismannian constraints on variation, i.e., no physiological mechanism whereby changes in soma cells could affect germ cells (Kellogg 1907: Bowler 1988; see also Gayon 1998). The great achievement of the modern evolutionary synthesis was to forge a synthesis of Mendelian genetics and Darwinian selection through the formulation of population genetics. Depew and I have argued that this transformation was possible through changing from Newtonian systems dynamics as part of the auxiliary assumptions of the Darwinian research tradition to a probabilistic, or what we termed Bolzmannian systems dynamics, evidenced in the work of J. B. S. Haldane, Sewall Wright, and especially Ronald Fisher. Natural selection in this description came to be considered as causing, and could be measured by, changes in gene frequencies. Indeed, changes in the gene frequencies of an interbreeding population that differed from the null hypothesis of the Hardy-Weinberg equilibrium, if no migration, mutation, or genetic drift occurred, could now be taken as indication of the action of natural selection and positive or negative selection coefficient calculated. Thus, even as common descent became accepted as a phenomenon as well as natural selection as a phenomenon, the theory of natural selection was recast in a more abstract manner with new theoretical terms that were articulated to the phenomena to be explained (for example common descent, adaptation, speciation) by mathematical formulae in the modern evolutionary synthesis.

The further argument made by Depew and myself was that, as stunningly successful as the modern evolutionary synthesis has been, additional facts from molecular and developmental biology have not merely provided additional new and significant lines of evidence for common descent but that they also have indicated that evolutionary phenomena may be more complex than as it is codified and explained by neo-Darwinism. The occurrence and role of neutral molecular mutations, or of mutations in the transcription factors that provide crucial information for development, for example, while not contradictory to neo-Darwinism in any way, were not anticipated but required additions and/or modifications in 
the explanatory framework (Depew and Weber 1985). Some Darwinians, while fully accepting the reality of common descent, have suggested that some form of modification and/or expansion of the synthesis might be needed to accommodate these new findings and perspectives, possibly deploying the resources of complex systems dynamics (Eldredge 1985; Wicken 1987; Kauffman 1993, 1995, 2000; Goodwin 1994; Depew and Weber 1995; Weber and Depew 1996, 2001; Griffiths and Gray 2001; Shanks 2004; Corning 2005; Williams and Fraústo da Silva 2006). Others have argued than neo-Darwinism is too brittle a theory to survive the inclusion of such new facts and phenomena and needs to be replaced by a new theory more along Geoffroyian or Lamarckian lines (Ho and Saunders 1984; Oyama 1985; Campbell 1985; Salthe 1993; Jablonka and Lamb 1995; Steele et al. 1998). Depew and I argued that, just as Darwinism renewed and reinvigorated itself through the modern evolutionary synthesis, it is possible that complex systems dynamics (including but not limited to non-linear dynamics, nonequilibrium thermodynamics, information theory, chaos theory, and self-organization), if adopted as auxiliary assumptions, could produce a new synthesis or program within the Darwinian research tradition that would not only robustly explain new facts and phenomena but point the way toward interesting new lines of research, as any good progressive research program should. Only if such an attempt fails should we look beyond Darwinian types of explanation. New facts and factual inferences do put pressure on the received theories to explain them, but if new auxiliary assumptions can better connect to phenomena while preserving the core of the tradition, then it is more reasonable to see how well such a revision works before junking the whole tradition. Each new fossil or sequence discovered always has the potential to falsify the inference of common descent, or such findings might prove to be beyond the explanatory limits of natural selection however conceived - but so far, to paraphrase Jane Austen, it could have come out that way, but it hasn't. Of course the putative program that would seek to replace the modern evolutionary synthesis has to prove itself by greater explanatory power and fecundity of new research questions now able to be delineated. Since phenomena are more stable than individual facts, it should be the former that drive theory change if it is needed. Data that are accepted as facts are open to subsequent revision if they are shown to be artifacts or fraudulent. That the so-called Piltdown Man proved to be a fraud does not falsify common descent as a phenomenon, since so many other fossils and indeed other lines of evidence have been and continue to be validated.

Before considering the current debates spurred by ID advocates primarily motivated by concerns outside the practice of evolutionary biology, I would like to pause to quickly consider, as a case study, the way in which the Baldwin effect was considered by various groups of evolutionary biologists working within the Darwinian research tradition. Depending upon their commitments to differing background assumptions and dynamical systems, the Baldwin effect was viewed as a possible fact, a possible phenomenon, an addition to evolutionary theory, or as non-existent, or if true only trivially so.

\section{The Baldwin Effect and Its Many Aspects}

In the 1890 s, in response to the impact of the "Weismann barrier" between soma and germ-line cells, which cut off possible Lamarckian mechanisms and pangenesis, evolutionary biologists and psychologists sought to find ways to account for possible rapid evolution or for a significant role of behavior and even mind in evolution within Darwinian terms (Weismann 1891, 1893; Romanes 1893; Baldwin 1896; Lloyd Morgan 1896; Osborn 1896). After an initial period of interest the effect, in light of the modern evolutionary synthesis at midcentury, what was then christened the "Baldwin effect" was considered false, or if true either irrelevant or only trivially so (Simpson 1953). Recent work on artificial intelligence (AI) has renewed interest in the possible efficacy of such an effect as a phenomenon and as a possible expansion of Darwinian explanatory repertoire for AI and much more (Hinton and Nowland 1987; Dennett 1995, 2003; Michel and Moore 1995; Deacon 1997, 2003). Recently, two books on the Baldwin effect have appeared (Weber and Depew 2003; Plotkin 2004).

Briefly, we can describe the Baldwin effect (in current language) in the following manner. If there is a stable (over generational time) selection pressure due to some aspect of the environment that sorts among nonheritable variations in behavior, and if that behavior can be transmitted by mimesis, or other forms of learning, to the next generation, then, not only can there can be selection for that behavior, but any genetic changes that make learning the behavior easier or which facilitate the behavior will be favored (what Baldwin termed "organic selection"). This allows the possibility of rapid behavioral change that is stabilized more slowly in the genome, while observing the Weismannian barrier because the behavior does not change the inheritance or development of the organism directly. In effect, the Baldwin effect buys "breathing space" for organisms that discover a useful trick until a genetic support is selected (Godfrey-Smith 2003).

In the early 20th century, as Mendelism was rediscovered, there continued to by an all-or-nothing view of selection (the "fly swatter" model of selection in which an organism was adapted or not and survived or not), which was consistent with a possible role for the Baldwin effect. As Depew (in press) has commented, R. A. Fisher's application of statistical biometry to genes not only created population genetics but also undercut "all-or-nothing" models of selection and gave room for natural selection to be a good enough process to eliminate the need for such notions as sexual selection or organic selection as separate forms of selection. Although Julian 
Huxley (1942: 114) was a booster of the Baldwin effect and Gaylord Simpson (1953) found it to be a theoretical possibility (i.e., consistent with the fundamental principles of the modern evolutionary synthesis), Simpson doubted its causal efficacy and existence as a phenomenon. A decade later Ernst Mayr (1963: 211) recommended "discarding this concept altogether" as being either trivially true or else leaving an opening for some form of neo-Lamarckianism. After Hinton and Nowland (1987) showed the potential usefulness of the concept, and John Maynard Smith (1987) supported the Baldwin effect as possibly a real phenomenon and a causal explanation, it was picked up by Dennett (1995) and Deacon (1997). In the light of notions of niche construction in the work of Richard Lewontin (1983) and John Odling-Smee (Odling-Smee et al. 2003) the Baldwin effect is congruent with ideas that organisms co-adapt with their environments to which they adapt and are adapted. As Depew points out, this placing of agency in organisms in populations undercuts a genocentric Darwinism but favors a broader conception of an extended phenotype in which "natural selection operates at the intersection between organisms and environments" (Depew in press). Against the background of a suitably expanded and enriched synthesis, possibly informed by complex systems dynamics, developmental plasticity explored by developmental systems theorists Susan Oyama, Paul Griffiths and Russell Gray (Oyama et al. 2001) and by Mary Jane West-Eberhard (2003) is not only congenial for the Baldwin effect, but the Baldwin effect can reasonably be added to the explanatory repertoire of the Darwinian research tradition (Deacon 2003; Depew 2003; Downes 2003; Griffiths 2003; Weber 2003).

With the Baldwin effect, we see its changing status as a possible phenomenon and a possible source of causal explanation differing depending upon the set of auxiliary assumptions and conceptual background of different phases of the Darwinian research tradition (a theoretical possibility, a non-phenomenon, trivially true, or causally important). Such analysis is aided by making the distinction between the experimental and observational facts, the inferred phenomenon, and the possible role of such an mechanisms in the explanatory theory of Darwinism. While I have gone through this quickly, I hope that the utility of such an approach as I am suggesting to analyses of dissent and controversy within science can be appreciated. I now turn to its application to dissent and controversy about Darwinism more generally, and specifically to consider the current challenge from those espousing "intelligent design," or ID.

\section{Evolutionary Fact, Phenomenon, and Theory in Light of the ID Challenge}

ID theorists follow a strategy of creationist critics of evolution generally by attacking one or more of the three aspects of fact, phenomenon and theory.
It is useful to reiterate what are the facts, the phenomena, and the theories involved. The facts are the fossils, the DNA and protein sequences, the comparisons of anatomy, embryology, physiology of extant organisms, geographical distributions of animals and plants, and even experiments to see, for example, if new enzyme traits can appear that have enhanced survival value or how mutations could affect the evolutionary trajectory starting from a putative ancestral protein sequence (Bridgham et al. 2006; Weinreich et al. 2006). The phenomena that are inferred are adaptation, descent with modification, and most generally common descent. Any theory explaining these phenomena that carries the Darwinian label will have at its core a major (though not necessarily sole) role for natural selection however it is conceptualized.

The criticisms are that the facts are incorrect (fraudulent or misinterpreted fossils for example), or that the phenomenon does not occur (common descent is not real but only reflects an apparent pattern due to the special actions bringing species into existence according to the will and mind of the Creator), or that even if common descent is accepted as a real, natural phenomenon, natural selection is not causally sufficient to account for it. Philip Johnson and Jonathan Wells follow all three of these lines of arguments in their desire of "splitting the foundations of naturalism" (Johnson 1993, 2000; Wells 2000). Although natural selection is admitted as something that occurs as a phenomenon (the appearance of antibiotic resistance in bacteria for example), it is not considered sufficient to cause speciation or the appearance of novel traits. Both Wells and Johnson reject common descent as a phenomenon, and Wells in particular finds evidence of fraud in many of the facts supporting evolutionary claims, even where most scholars do not. Their colleague Michael Behe (1996), on the other hand, is willing to accept common descent as a real phenomenon in nature as well as allowing that speciation could be due to natural selection. Behe, however, repeatedly asserts that a number of important biological traits (vision, blood clotting, the immune response) could not emerge through the action of natural selection, and combines this with what Depew and I have called his argument from incredulity, or "how possibly" could a particular trait X (blood clots, the immune system, a flagellum) have arisen by natural causes? Since the author advancing such arguments cannot conceive of how natural selection or any other natural process could produce such functional "irreducible" complexity we are left with the argument to the only alternative, set out in the premises to be design, the advantage being no support is needed for the alternative once natural causes are "eliminated." For such traits natural selection is regarded as impotent and these traits must have arisen by the agency of an intelligent designer (see Weber and Depew 2004 for an analysis of the fallacies of such arguments). It is important to be aware of what is specifically being challenged, the facts, the phenomena, or the theory used to explain the phenomenon 
in question. In what follows I will specifically concentrate on a particular critique by Wells of common descent as a phenomenon as analyzed by Jim Hofmann and myself (Hofmann and Weber 2003).

Because the thesis of common descent as a phenomenon has explanatory power in terms of correlating a large number of independent lines of evidence, it has been criticized as being "only a theory." Although it does correlate a number of observations- just as Kepler's laws make sense out of a large body of empirical observations about planetary motioncommon descent per se does not function to explain why a particular fossil has a particular shape or is found in a particular stratum of rock. Common descent is inferred from the facts and then a theory is needed that explains why common descent occurs. This is what Darwin provided in his theory of natural selection, if appropriate auxiliary assumptions and observations are included to connect the theory to the specifics in question. The confusion, which is exploited by the critics of evolutionary biology, lies in the ambiguity of the term evolution, which can stand for the phenomenon of common descent or for the theory of natural selection, which explains common descent. Wells not only takes advantage of this ambiguity but he also tries to argue that disputes and dissent within the scientific community, particularly in how to relate sequences to fossils and how to date when sequences from contemporary species last shared a common ancestor, demonstrate that there is no such thing as common descent.

Evidence obtained by analyzing the comparisons of protein, DNA, and RNA sequences are particularly compelling to almost all biologists in that they represent a line of evidence quite distinct from those based upon comparative morphology and anatomy, comparative embryology, or biogeography, representing a line of evidence not available until the last third of the 20th century, and which can be subjected to intensive statistical and computer analysis. Such studies show overwhelming evidence for thousands of genes and gene products from thousands of diverse and disparate contemporary species, of common descent. From such quantitative data it is possible to construct statistically plausible phylogenetic trees relating either the species from which the molecules were derived or the pattern of relation in evolutionary time of the genes themselves (Lewin 1999). Concurrently, the elucidation of the three-dimensional structure of many hundreds of proteins from a variety of species has demonstrated that there is a stability of the folded structure of proteins (thereby maintaining biological function) despite considerable (though not unrestricted) variation in the amino acid sequences of these proteins. These observations, along with developments in the mathematical theories of population genetics, led to the concept of neutral molecular mutations (Kimura 1968, 1983; King and Jukes 1969). Since these neutral mutations appear to occur roughly as a function of geological time, it is possible to utilize them as a type of "molecular clock" to provide approximate dates for the appearance of a gene and/or to specify when two extant species last shared a common ancestor (Zuckerkandl and Pauling 1965; Kimura 1987; Zuckerkandl 1987). The molecular evolutionists pursuing such studies, of course, have disputes and dissent as to the proper methods for calculating phylogenetic trees or for how to calibrate and deploy the molecular clock, but gradually methods are being improved and refined, and the disputes narrowed (Futuyma 1998; Li 1997; Page and Holmes 1998).

With the advent of genome sequencing, an additional line of evidence has become available with the surprising observation that a considerable portion of genomic DNA has been derived from RNA viral infections (Li 1997; Li et al. 2001; Page and Holmes 1998). Comparisons of such retroviral sequences among species can provide information about which more recently shared a common ancestor. For example, comparison of 13 retroviral sequences in the genomes of whales, hippos, camels, deer, giraffes, and pigs demonstrate that whales are more closely related to hippopotami and more distantly related to deer, pigs, and camels, and, by using the molecular clock, that the last common ancestor to whales and hippos existed about 55 million years ago, just before the estimated date of Himalayacetus, the earliest known whale fossil (Nikaido et al. 1999).

\section{Response to Wells's Objections to Such Molecular Evidence for Common Descent}

Wells cites a large number of papers from the primary molecular evolutionary literature, emphasizing that differences in methodologies and interpretations renders all the molecular evidence for common descent, or as Wells calls it, "Darwin's theory," suspect (Wells 2000). Further, he argues that genome studies of prokaryotes and the Archaea have "uprooted" the "tree of life" and have thus falsified common descent. Wells cites disagreements about specific phylogenetic trees or the dating of times of appearance of a gene or the last common ancestor, giving the impression that the scientists involved were doubting common descent rather than arguing about validity of data, statistical and computational approaches, or which mathematical models should be used to instantiate the formulation of the theories being used. Wells makes much of the "Cambrian explosion" of metazoa around 543 million years ago, especially as estimates of the time of divergence of animal phyla, based upon molecular data, range from 0.57 to 1.2 billion years ago. Although citing differences of opinion about how to apply molecular clocks that give rise to this range of dates, Wells ignores important literature that indicates that animal divergence began around 400 million years before the beginning of Cambrian (Wang et al. 1999). Further, it is increasingly clear that there is not a strict coupling 
of most genes (especially those coding for proteins involved in metabolism) and organismic morphological changes, but rather the correlation is to be found in those specific genes involved in development, which we can now study and understand (Wilson et al. 1977; Gilbert 1997; Shubin et al. 1997; Gehring 1998; Conway Morris 2000; Carroll et al. 2001; Carroll 2005). James Valentine and his colleagues have argued that there were changes in Hox genes (some of the genes involved in development) and their arrangement in the genome about the time of the Cambrian explosion, but that the genes themselves appear to have originated hundreds of millions of years earlier in the Ediacaran (Valentine et al. 1999; see also McMenamin 1998).

Another main line of argument that Wells pursues is his claim that the work of Carl Woese and W. Ford Doolittle gives the coup de grace that uproots the tree of life because of their evidence that there was considerable horizontal gene transfer within various bacterial taxa and within Archaea taxa, as well as between them (Woese 1998; Doolittle 1999, 2000). This complexity means that we are unable to identify the common ancestor of all life but only a "pregenate ancestral core" from which the three domains of Eubacteria, Archaea and Eukaryota emerge (Woese 1998, 2002). This hardly "uproots the tree of life" as Wells claims, but rather shows that life is a bit more complex than we had assumed with an initial web of lineages that might be likened to a complex root system of a thicket or a multi-trunk tree. Does this falsify or even threaten Darwin's claim of common descent by natural selection? Darwin himself even allowed for more than one original form into which life, as he put it was "breathed" (Darwin 1859: 490).

Throughout Icons of Evolution Wells ambiguously equates and conflates evolution, common descent, Darwin's theory, and philosophical materialism. Legitimate arguments about data or dissent about which particular version of Darwinian theory is most appropriately employed are taken to falsify all aspects of the Darwinian research tradition and evolutionary biology more generally. But if we carefully distinguish between data, and when such data can be considered to be validated and come to be accepted as facts on the one hand, and various versions of the causal explanatory theory on the other, we can begin to make some progress. But we need to go further. Not only do distinctions need to be made between those assumptions accepted for methodological reasons and those representing extrascientific philosophical inference or commitment, but we need to utilize the intervening role Bogen and Woodward posit for phenomena. None of the authors cited by Wells doubted the phenomenon of common descent, but they did disagree about which data were valid, how such data should be analyzed, what theoretical tools should be employed to interpret and explain the data and related them to common descent. Such debate, dissent, and controversy within science is a sign of a healthy, progressive research program.
Rumors of the eminent demise of Darwinism or evolutionary biology are indeed premature.

\section{Parting Thoughts}

My goal here has been to offer a useful perspective for approaching controversy and dissent within the Darwinian framework specifically and more generally in the context of the broader discourse about evolution, rather than to present a complete or definitive response to such issues (although I think such responses are possible and apparent). By positioning a phenomenon between the data and facts that lend it support and the theories that may explain it, clarity can be brought to understanding what is at issue in the disagreements. Disputes about facts can of course have implications for the validity of an inferred phenomenon or the theory or theories used to explain the phenomenon, but such disputes do not per se mean the phenomenon is automatically falsified. More generally, different theorists, working in the same or different research traditions, can differ as to which version of a theory, or which theory, or more broadly which program or tradition, is robust enough to account for the phenomena of concern and to have fecundity for guiding further research. So situated, the explanatory power and fecundity of the Darwinian research tradition can be favorably compared with other research traditions and to putative alternatives such as ID.

\section{Acknowledgments}

A version of this paper was presented at the Centre for the Philosophy of Natural and Social Sciences, London School of Economics, on 13 June 2006, as part of the Dissent in Science seminar series. I wish to thank David Depew, James Hofmann, and James Moore for reading and commenting upon an earlier version of this paper.

\section{References}

Aronova E (2007) Karl Popper and Lamarckism. Biological Theory 2: 37-51. Baldwin JM (1896) A new factor in evolution. American Naturalist 30: 441451, 536-553.

Behe MJ (1996) Darwin's Black Box: The Biochemical Challenge to Evolution. New York: Free Press.

Bogen J, Woodward J (1988) Saving the phenomena. Philosophical Review 97: 303-352.

Bowler PJ (1988) The Non-Darwinian Revolution. Baltimore: Johns Hopkins University Press.

Bree CR (1872) An Exposition of Fallacies in the Hypothesis of Mr. Darwin. London: Longmans.

Bridgham JT, Carroll SM, Thornton JW (2006) Evolution of hormone-receptor complexity by molecular exploitation. Science 312: 97-101.

Campbell JH (1985) An organizational interpretation of evolution. In: Evolution at a Crossroads (Depew DJ, Weber BH, eds), 133-167. Cambridge, MA: MIT Press.

Carroll SB (2005) Endless Forms Most Beautiful: The New Science of Evo Devo. New York: Norton.

Carroll SB, Grenier JK, Weatherbee SC (2001) From DNA to Diversity: Molecular Genetics and the Evolution of Animal Design. Malden, MA: Blackwell. 
Conway Morris S (2000) Evolution: Bringing Molecules into the Fold. Cell 100: $1-11$.

Corning P (2005) Holistic Darwinism: Synergy, Cybernetics, and the Bioeconomics of Evolution. Chicago: University of Chicago Press.

Darwin CR $(1851,1854,1858)$ A Monograph of the Sub-Class Cirripedia. London: The Ray Society [1851 and 1854], and A Monograph of the Fossil Lepadida, London: Paleontological Society [1858].

Darwin CR (1859) On the Origin of Species by Means of Natural Selection or the Preservation of Favored Races in the Struggle for Life. London: John Murray.

Darwin CR (1862) On the Various Contrivances by which British and Foreign Orchids Are Fertilized by Insects, and on the Good Effects of Intercrossing. London: John Murray.

Darwin CR (1868) The Variation of Animals and Plants under Domestication. London: John Murray.

Deacon TW (1997) The Symbolic Species: The Co-evolution of Language and the Brain. New York: Norton.

Deacon TW (2003) Multilevel selection in a complex adaptive system: The problem of language origins. In: Evolution and Learning (Weber BH, Depew DJ, eds), 81-106. Cambridge, MA: MIT Press.

Dennett DC (1995) Darwin's Dangerous Idea: Evolution and the Meanings of Life. New York: Simon and Schuster.

Dennett DC (2003) The Baldwin effect: A crane, not a skyhook. In: Evolution and Learning (Weber BH, Depew DJ, eds), 69-79. Cambridge, MA: MIT Press.

Depew DJ (2003) Baldwin and his many effects. In: Evolution and Learning (Weber BH, Depew DJ, eds), 3-31. Cambridge, MA: MIT Press.

Depew DJ (in press) The evolution of Darwinism and the Baldwin effect. In: Atti el Convergno: Epigenetica: Un nuovo modello per la complessita nella scienze e nella filosofia (Stanzione M, ed). Roma: Università di Roma Press.

Depew DJ, Weber BH (1985) Innovation and tradition in evolutionary theory. In: Evolution at a Crossroads (Depew DH, Weber BH, eds), 227-260. Cambridge, MA: MIT Press.

Depew DJ, Weber BH (1995) Darwinism Evolving: Systems Dynamics and the Genealogy of Natural Selection. Cambridge, MA: MIT Press.

Doolittle WF (1999) Phylogenetic classification and the universal tree. Science 202: 2124-2148.

Doolittle WF (2000) Uprooting the tree of life. Scientific American 282(2): 90-95.

Downes SM (2003) Baldwin effects and the expansion of the explanatory repertoire in evolutionary biology. In: Evolution and Learning (Weber BH, Depew DJ, eds), 33-51. Cambridge, MA: MIT Press.

Eldredge N (1985) Unfinished Synthesis: Biological Hierarchies and Modern Evolutionary Thought. New York: Oxford University Press.

Futuyma DJ (1998) Evolutionary Biology. 3rd ed. Sunderland, MA: Sinauer. Gale BG (1982) Evolution without Evidence: Charles Darwin and The Origin of Species. Albuquerque: University of New Mexico Press.

Gayon J (1998) Darwinism's Struggle for Survival. Cambridge: Cambridge University Press.

Gehring WJ (1998) Master Control Genes in Development and Evolution. New Haven: Yale University Press.

Ghiselin MT (1969) The Triumph of the Darwinian Method. Berkeley: University of California Press.

Gilbert GN, Mulkay M (1984) Opening Pandora's Box: A Sociological Analysis of Scientists' Discourse. Cambridge: Cambridge University Press.

Gilbert SF (1997) Developmental Biology. 5th ed. Sunderland MA: Sinauer.

Godfrey-Smith P (2003) Between Baldwin skepticism and Baldwin boosterism. In: Evolution and Learning (Weber BH, Depew DJ, eds), 53-67. Cambridge, MA: MIT Press.
Goodwin BC (1994) How the Leopard Changed Its Spots: The Evolution of Complexity. London: Weidenfeld and Nicolson.

Gould SJ (1983) Evolution as fact and theory. In: Gould SJ, Hen's Teeth and Horse's Toes, 253-262. New York: Norton.

Griffiths PE (2003) Beyond the Baldwin effect: James Mark Baldwin's “social heredity," epigenetic inheritance, and niche construction, in Evolution and Learning (Weber BH, Depew DJ (eds), 193-215. Cambridge, MA: MIT Press.

Griffiths PE, Gray RD (2001) Darwinism and developmental systems. In: Cycles of Contingency (Oyama S, Griffiths PE, Gray RD, eds), 195-218. Cambridge, MA: MIT Press.

Hinton GE, Nowland SJ (1987) How learning can guide evolution. Complex Systems 1: 495-502.

Ho M-W, Saunders PT, eds (1984) Beyond Neo-Darwinism: An Introduction to the New Evolutionary Paradigm. London: Academic Press.

Hofmann JR, Weber BH (2003) The fact of evolution: Implications for science education. Science and Education 12: 729-760.

Huxley JS (1942) Evolution: The Modern Synthesis. London: Allen and Unwin.

Humes E. (2007) Monkey Girl: Evolution, Education, Religion, and the Battle for the American Soul. New York: Harper Collins.

Jablonka E (2001) The systems of inheritance. In: Cycles of Contingency (Oyama S, Griffiths PE, Gray RD, eds), 99-116. Cambridge, MA: MIT Press.

Jablonka E, Lamb MJ (1995) Epigenetic Inheritance and Evolution: The Lamarckian Dimension. Oxford: Oxford University Press.

Johnson PE (1993) Darwin on Trial. 2nd ed. Downers Grove, IL: InterVarsity Press.

Johnson PE (2000) The Wedge of Truth: Splitting the Foundations of Naturalism. Downers Grove, IL: InterVarsity Press.

Kauffman SA (1993) The Origins of Order: Self-Organization and Selection in Evolution. New York: Oxford University Press.

Kauffman SA (1995) At Home in the Universe: The Search for the Laws of Self-Organization and Complexity. New York: Oxford University Press.

Kauffman SA (2000) Investigations. New York: Oxford University Press.

Kellogg V (1907) Darwinism Today: A Discussion of Present-Day Scientific Criticism of the Darwinian Selection Theories. New York: Holt.

Kimura M (1968) Evolutionary rate at the molecular level. Nature 217: 624 626.

Kimura M (1983) The Neutral Theory of Molecular Evolution. Cambridge: Cambridge University Press.

Kimura M (1987) Molecular evolutionary clock and the neutral theory. Journal of Molecular Evolution 26: 24-33.

King JL, Jukes TH (1969) Non-Darwinian evolution. Science 164: 788-798.

Lakatos I (1970) Falsification and the methodology of scientific research programmes. In: Criticism and the Growth of Knowledge (Lakatos I, Musgrave A, eds), 91-195. Cambridge: Cambridge University Press.

Lakatos I (1978) The Methodology of Scientific Research Programmes. Cambridge: Cambridge University Press.

Laudan L (1977) Progress and Its Problems: Toward a Theory of Scientific Growth. Berkeley and Los Angeles: University of California Press.

Lewin R (1999) Patterns in Evolution: The New Molecular View. New York: Scientific American Press.

Lewontin RC (1983) Gene, organism and environment. In: Evolution From Molecules to Men (Bendall DS, ed), 273-285. Cambridge: Cambridge University Press.

Li W-H (1997) Molecular Evolution. Sunderland, MA: Sinauer.

Li W-H, Gu Z, Wang H, Nekrutenko A (2001) Evolutionary analysis of the human genome. Nature 409: 847-848.

Lloyd Morgan C (1896) Of modification and variation. Science 4: 733-739. 
McMenamin MAS (1998) The Garden of Ediacara: Discovering the First Complex Life. New York: Columbia University Press.

Maynard Smith J (1987) Natural selection: When learning guides evolution. Nature 329: 761-762.

Mayr E (1963) Animal Species and Evolution. Cambridge, MA: Harvard University Press.

Michel GF, Moore CL (1995) Developmental Psychobiology: An Interdisciplinary Science. Cambridge, MA: MIT Press.

Mivart StG (1871) On the Genesis of Species. London: Macmillan.

Moore J (1991) Deconstructing Darwinism: The politics of evolution in the 1860s. Journal of the History of Biology 24: 353-408.

Mulkay M (1985) The Word and the World: Explorations in the Form of Sociological Analysis. London: Allen and Unwin.

Müller F (1869) Facts and Arguments for Darwin Dallas WS, trans). London: John Murray. German orig. 1863.

Nikaido M, Rooney AP, Okada N (1999) Phyogenetic relationships among certariodactyls based upon insertions of short and long interspersed elements: Hippopotamuses are the closest extant relatives of whales. Proceedings of the National Academy of Sciences 98: 9707-9712.

Odling-Smee FJ, Laland KN, Feldman MW (2003) Niche Construction: A Neglected Process in Evolution. Princeton: Princeton University Press.

Osborn HF (1896) A mode of evolution requiring neither natural selection nor the inheritance of acquired characteristics. Transactions of the New York Academy of Science 15: 141-148.

Oyama S (1985) The Ontogeny of Information. Cambridge: Cambridge University Press.

Oyama S, Griffiths PE, Gray RD, eds (2001) Cycles of Contingency: Developmental Systems and Evolution. Cambridge, MA: MIT Press.

Page RDM, Holmes EC (1998) Molecular Evolution: A Phylogenetic Approach. Oxford: Blackwell.

Paley W (1802) Natural Theology Or, Evidences of the Existence and Attributes of the Deity, Collected from the Appearances of Nature. London: Faulder.

Plotkin H (2004) Evolutionary Thought in Psychology: A Brief History. Oxford: Blackwell.

Prebble J, Weber BH (2003) Wandering in the Gardens of the Mind: Peter Mitchell and the Making of Glynn. New York: Oxford University Press.

Romanes GJ (1893) An Examination of Weismannism. Chicago: Open Court.

Ruse M (1982) Darwinism Defended: A Guide to the Evolutionary Controversies. Reading, MA: Addison-Wesley.

Salthe SN (1993) Development and Evolution: Complexity and Change in Biology. Cambridge, MA: MIT Press.

Sarfati J (2002) Refuting Evolution 2. Green Forest, AR: Master Books.

Shanks N (2004) God, the Devil, and Darwin. New York: Oxford University Press.

Shubin N, Tabin C, Carroll S (1997) Fossils, genes and the evolution of animal limbs. Nature 388: 639-648.

Simpson GG (1953) The Baldwin effect. Evolution 7: 110-117.
Steele EJ, Lindley RA, Blanden RV (1998) Lamarck's Signature: How Retrogenes are Changing Darwin's Natural Selection Paradigm. Reading, MA: Perseus Books.

Talbot M (2005) Darwin in the dock: Intelligent design has its day in court. New Yorker (5 December): 66-77.

Valentine JW, Jablonski D, Erwin DH (1999) Fossils, molecules and embryos: New perspectives on the Cambrian explosion. Development 126: 851-859.

Wang DY-C, Kumar S, Blair Hedges S (1999) Divergence time estimates for the early history of animal phyla and the origin of plants, animals and fungi. Proceedings of the Royal Society of London B 226: 163-171.

Weber BH (2003) Emergence of mind and the Baldwin effect. In: Evolution and Learning (Weber BH, Depew DJ, eds), 309-326. Cambridge, MA: MIT Press.

Weber BH, Depew DJ (1996) Natural selection and self-organization: Dynamical models as clues to a new evolutionary synthesis. Biology and Philosophy 11: 33-65.

Weber BH, Depew DJ (2001) Developmental systems, Darwinian evolution and the unity of science. In: Cycles of Contingency (Oyama S, Griffiths PE, Gray RD, eds), 239-253. Cambridge, MA: MIT Press.

Weber BH, Depew DJ, eds (2003) Evolution and Learning: The Baldwin Effect Reconsidered. Cambridge, MA: MIT Press.

Weber BH, Depew DJ (2004) Darwinism, design, and complex systems dynamics. In: Debating Design: From Darwin to DNA (Dembski WA, Ruse R, eds), 173-190. Cambridge: Cambridge University Press.

Weinreich DM, Delaney NF, DePristo MA, Hartl DL (2006) Darwinian evolution can follow only very few mutational paths to fitter proteins. Science 312: 111-114.

Weismann F (1891) Essays on Heredity and Kindred Problems (Poulton E et al., eds). Oxford: Clarendon Press.

Weismann F (1893) The all-sufficiency of natural selection: A reply to Herbert Spencer. Contemporary Review 64: 309-338. 596-610.

Wells J (2000) Icons of Evolution Science or Myth? Why Much of What We Teach About Evolution Is Wrong. Washington DC: Regnery.

West-Eberhard MJ (2003) Developmental Plasticity and Evolution. Oxford: Oxford University Press.

Whewell W (1837) History of the Inductive Sciences. 3 vols. London: Parker.

Wicken JS (1987) Evolution, Information and Thermodynamics: Extending the Darwinian Program. New York: Oxford University Press.

Williams RJP, Fraústo da Silva JJR (2006) The Chemistry of Evolution: The Development of Our Ecosystem. Amsterdam: Elsevier.

Wilson AC, Carlson SS, White TJ (1977) Biochemical evolution. Annual Reviews of Biochemistry 46: 573-639.

Woese C (1998) The universal ancestor. Proceedings of the National Academy of Sciences 95: 6854-6859.

Woese C (2002) On the evolution of cells. Proceedings of the National Academy of Sciences 99: 8742-8747.

Zuckerkandl E (1987) On the evolutionary clock. Journal of Molecular Evolution 26: 34-46.

Zuckerkandl E, Pauling L (1965) Molecules as documents of evolutionary history. Journal of Theoretical Biology 8: 357-366. 